\title{
平押し法によるかえりなしせん断製品の寸法精度に関する研究*
}

\author{
丸木 隆史 ${ }^{* 1}$, 齊藤 涁" ${ }^{* 1}$, 青木 勇 ${ }^{* 2}$
}

\section{Dimensional Accuracy on Burr-Free Blanked Products Obtained by Push-Back Blanking Method}

\author{
Ryuji MARUKI ${ }^{* 1}$, Akira SAITO and Isamu AOKI \\ ${ }^{* 1}$ Kanagawa Univ., Dept. of Mechanical Engineering \\ Rokkakubashi 3-27-1, kanagawa-ku, Yokohama, 221-8686 Japan
}

\begin{abstract}
The push-back blanking is easy for achieving perfect burr-free blanking. This method consists of two stages, that is, the 1st stage for making the half-blanked product, and the 2nd stage for pushing it back to the original thickness. Successful blanking conditions for burr-free have been investigated already. Applying the method to the manufacturing processes of precise mechanical parts more widely, dimensional accuracy of burr-free blanked products should be known. In this research, influence of material constraint conditions on dimensional error and shear droop is investigated. As the results, it is found that the employments of material constraint at 1st stage, strong blank holder and counter punch, improve the dimensional accuracy and reduce shear droop. Dimensional improvement mainly depends on the ideal shape of half -blanked specimen obtained at 1st stage using strong blank holder and counter punch.
\end{abstract}

Key Words : Burr-Free Blanking, Shearing, Dimensional Accuracy, Shear Droop, Clearance

\section{1. 緒言}

せん断加工で発生するかえりは鋭く脱落しやすいため, 作業者への傷害や機器の損傷の原因となる等の問題を もたらす．せん断条件の適正化と適切な工具管理で小さく抑えられるが，完全なかえりなしは困難である．その ため, 以前からかえりなしせん断法が検討されてきた. 対向する 2 組のパンチ・ダイスでせん断を行う上下抜き

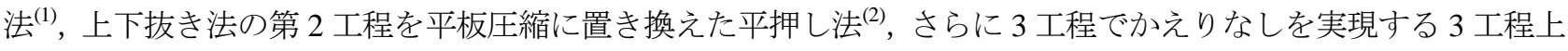
下抜き法 ${ }^{(3)}$ などが提案されている. 各種かえりなしせん断法の中で平押し法は比較的簡単な工法でかえりなしを 実現できることから，実際の適用が増えている．平押し法の加工機構や加工条件の影響についてはすでに幾つか の報告があり, かえりなし成功特性に及ぼすクリアランスと食い込み量の影響(4), 成功域に及ぼす逆押さえの影 響(5)，材料さん幅の影響(6)が調べられている．また，負のクリアランス条件拡張の諸影響(7)も調べられている．さ らに上下抜き法，平押し法に関寸る FEM 解析が行われ(8)，有益な結果が提示されている.

近年の機器の高精度化に伴い，せん断製品にも高精度化が求められており，平押し製品にも同様な検討が望ま れるが，寸法精度に関する研究は極めて限定的(5)である. ゼロクリアランスの平押し法によれば，寸法精度は向 上し切口面は板面に対してほぼ垂直となるが，分離しにくい．他方，クリアランスを負に大きくすると分離しや すくなるが，寸法精度は低下し切口面の傾きは増加するなどの問題がある. 平押し法は 2 工程を必要とし，各工 程で生じる材料変形が寸法精度と切口面性状に影響する。特に第 1 工程で被る材料変形に及ぼす材料拘束の影響 は大きいと考えられる，このような事情で，本研究では，平押し製品の寸法精度と切口形面性状に及ぼす材料拘 束の影響について実験的に検討した結果を報告する.

\footnotetext{
* 原稿受付 2013 年 3 月 18 日

*1 学生員, 神奈川大学 工学部（干221-8686 神奈川県横浜市神奈川区六角橋 3-27-1）

*2 正員, 神奈川大学

E-mail:r201370104pa@kanagawa-u.ac.jp
} 


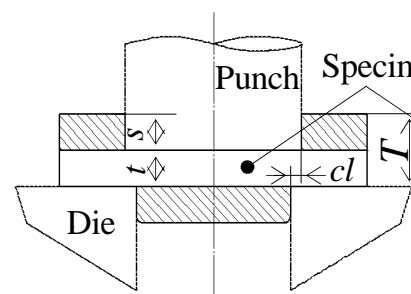

(a) 1st stage

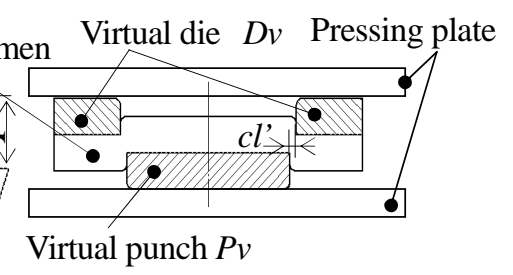

(b) 2nd stage

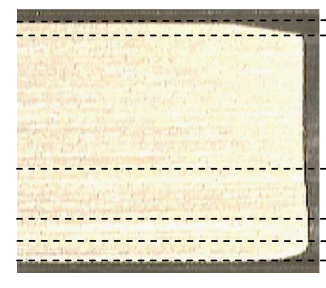

(a) Cross sectional view

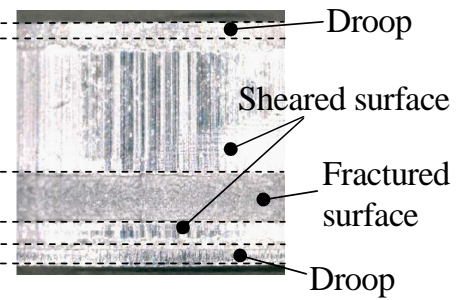

(b) Appearance

Fig.1 Push-back blanking process

Fig.2 Cut surface of burr-free blanked product

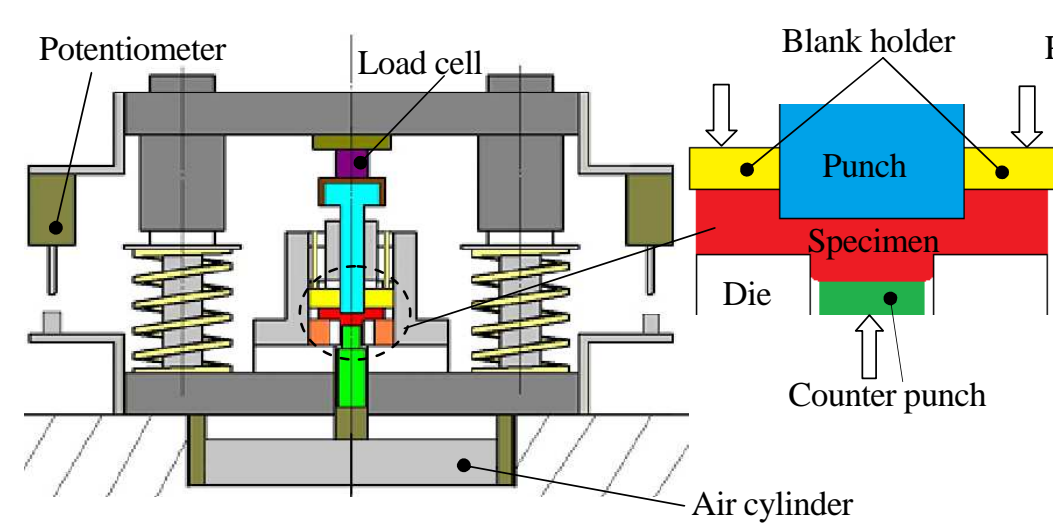

Fig.3 Experimental apparatus for 1st stage

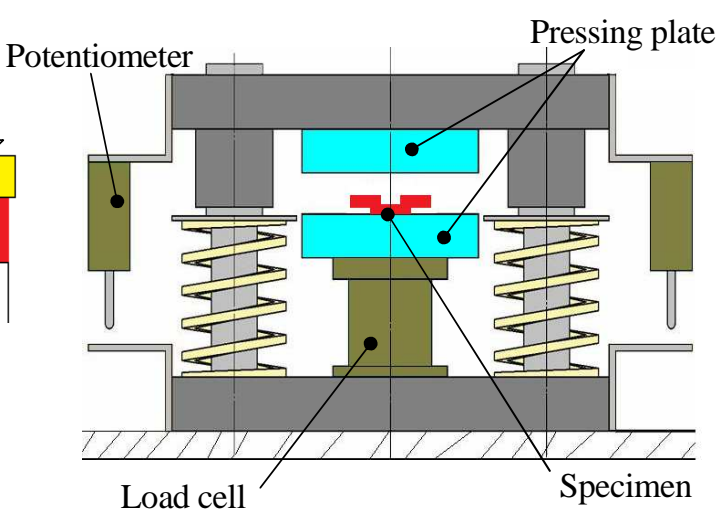

Fig.4 Experimental apparatus for 2nd stage

\section{2. 平押し法の加工原理}

平押し法は，図1(a)のようにゼロまたは負クリアランスで板厚 $T$ の 60 80\%程度せん断する第 1 工程と，これ を平板工具で押し戻し，材料から製品を分離する第 2 工程からなる．本法では試験片の板面上下の端部にだれを 形成し，かえりの発生を防ぐことができる．また，本法の第 2 工程は仮想せん断として考えることができる.す なわち, 同図(b)のように，第 2 工程は第 1 工程で半抜きされた試験片の一部が仮想パンチ $P v$, 仮想ダイス $D v$ と なり，これら仮想工具で残留板厚 $t$ をせん断すると考えるのである. したがって第 2 工程を慣用せん断に類似さ せるためには, 第 1 工程を負クリアランス $c l$, 食い込み量を板厚比 60 80\%程度とする必要がある. 第 1 工程で クリアランスを負にすることで，第 2 工程のクリアランス $\mathrm{cl}$ ’が正となり，容易に分離する. こうしてできた製 品は図 2(a)のように板面上下にだれが形成され，かえりはない.

\section{3. 研究方法}

本研究では第 1 工程の実験条件, 特に試験片の拘束条件（板押さえ, 逆押さえ）によって発生する材料流動, だれ，わん曲などが寸法精度およびだれに及ぼす影響を明らかにするため, 半抜きを行う第 1 工程で拘束条件 (板 押さえ力，逆押さえ力）を変え，平押しを行う第 2 工程における材料の変形挙動を調べる.

第 1 工程は図 3 に示寸高精度維持が容易な丸形同心型ダイセットを使用し，第 2 工程は図 4 に示寸平押しダイ セットを使用した。いずれの工程においても変位はポテンションメータで, 荷重はひずみゲージ形荷重計で測定 される. 第 1 工程, 第 2 工程ともにステップモータ駆動プレスを用い, 加工速度は $1 \mathrm{~mm} / \mathrm{s}$ (無負荷時) とした. 先行研究 ${ }^{(4,5)}$ より, 高い寸法精度が期待でき切口面の傾きが小さく, かつ分離しやすい加工条件 (パンチ径 $D_{p}$ : $15.369 \mathrm{~mm}$, ダイス径 $D_{d}: 15.145 \mathrm{~mm}$, クリアランス $\left.\mathrm{cl}:-3.73 \%\right)$ を選定した. 試験片は板厚 $T: 3 \mathrm{~mm}$ の純アルミニ ウム広幅板材 (JIS A1100P-O) から一辺 40mm の正方形に切り出したものを使用した. 材料の引張強さは 95MPa,

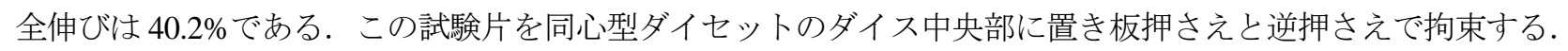
板押さえはねじ拘束とした. トルクレンチを用い, 締付トルクから加圧力を算出した. ここでは締め付け後の初 期ゆるみ等は特に考慮せず，板押さえ力の大きさの影響を概括的に調べることとした．逆押さえは空圧シリンダ を用いた. 第 1 工程における拘束条件を表 1 に示す. 板押さえ力は, 材料が降伏する直前の值を最大とし, これ 

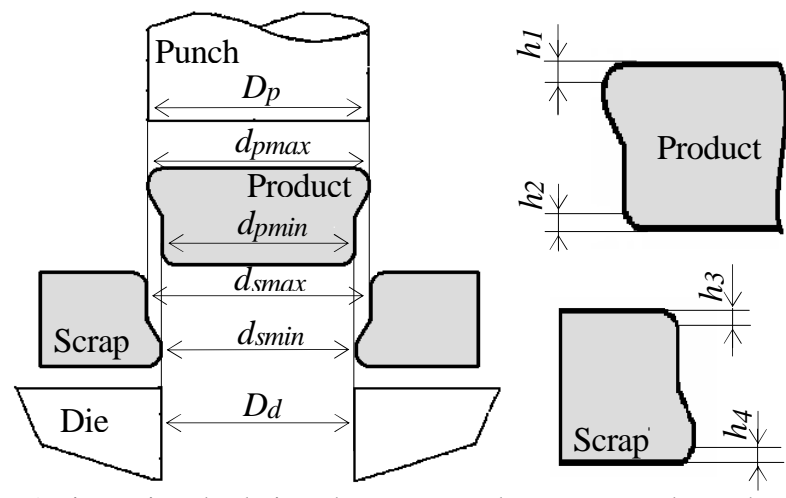

Fig.5 Dimensional relations between product, scrap and punch die at push-back blanking and definition of droop height

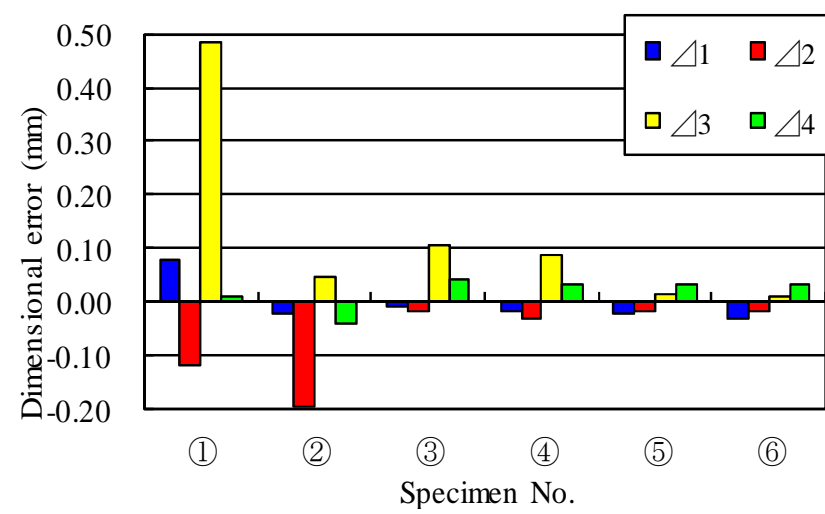

Fig.6 Dimensional error at 2nd stage
Table 1 Constraint conditions

\begin{tabular}{|c|c|c|}
\hline Specimen No. & $\begin{array}{c}\text { Blank holding force } \\
f(\mathrm{~N})\end{array}$ & $\begin{array}{c}\text { Counter force } \\
f^{\prime}(\mathrm{N})\end{array}$ \\
\hline (1) & - & - \\
\hline 2 & 100 & \multirow{2}{*}{3000} \\
\hline 3 & 100 & \\
\hline$(4)$ & 6500 & \\
\hline 5 & 15000 & \\
\hline 6 & 30000 & \\
\hline
\end{tabular}

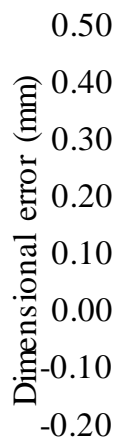

(1)

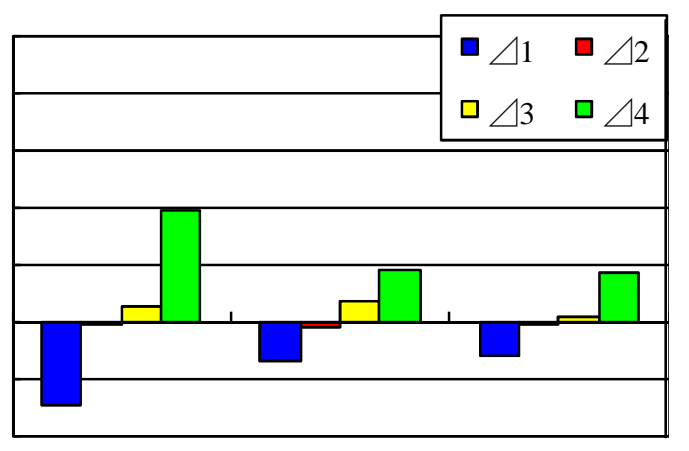

(3)

Specimen No.

(6)
Fig.7 Dimensional error at 1st stage

より小さい幾つかの值を設定した. 逆押さえ力は, 予備実験より製品のわん曲を十分防止できる值で一定とした.

第 1 工程でパンチを所定量試験片に食い込ませ，半抜き試験片を得る。これを第 2 工程の平押し工具で押し戻 し分離する. なお，分離後に製品のわん曲の平坦化などの変形が生じないように，不必要な平押しは続けていな い. その後，測定顕微鏡を用いて製品外径とか寸内径の寸法，だれ高さを測定する.

\section{4. 結果及び考察}

\section{$4 \cdot 1$ 寸法誤差}

図 5 に製品, か寸と工具寸法の関係ならびにだれ高さの定義を示す. 得られた製品寸法 $d_{p m a x}, d_{p m i n}$, および か寸寸法 $d_{s m a x}, \quad d_{s \min }$, とパンチ外径 $D_{p}$ またはダイス内径 $D_{d}$ との寸法誤差 $\Delta 1 \sim \Delta 4$ を以下のように定義する.

$$
\begin{array}{ll}
\triangle 1=d_{\text {max }}-D_{p} & \triangle 2=d_{\text {pmin }}-D_{d} \\
\triangle 3=d_{\text {smax }}-D_{p} & \triangle 4=d_{\text {smin }}-D_{d}
\end{array}
$$

寸法誤差に関する実験結果を図6に示す。これり以下のことがわかる.

(1) 試験片(1)より試験片(3は寸法誤差が全体的に小さく, 板押さえ, 逆押さえを用いたほうが寸法誤差を小さく できる.

(2) 試験片(1)は $\Delta 3$ がきわめて大きく, これと比較すると, 試験片(2)では $\Delta 1$ が $0.055 \mathrm{~mm}, \quad \Delta 3$ が $0.397 \mathrm{~mm}$ 小さ い. 板押さえによってかすの跳㸚上がりが抑えられるため, 製品, か寸寸法の誤差が小さくなったと考えられる.

(3) 試験片(3) と試験片(2)では, 試験片(3)の $\triangle 2$ が $0.175 \mathrm{~mm}, \Delta 4$ が $0.002 \mathrm{~mm}$ 小さくなる. 逆押さえによって製品 のわん曲が抑えられたためと考えられる. 


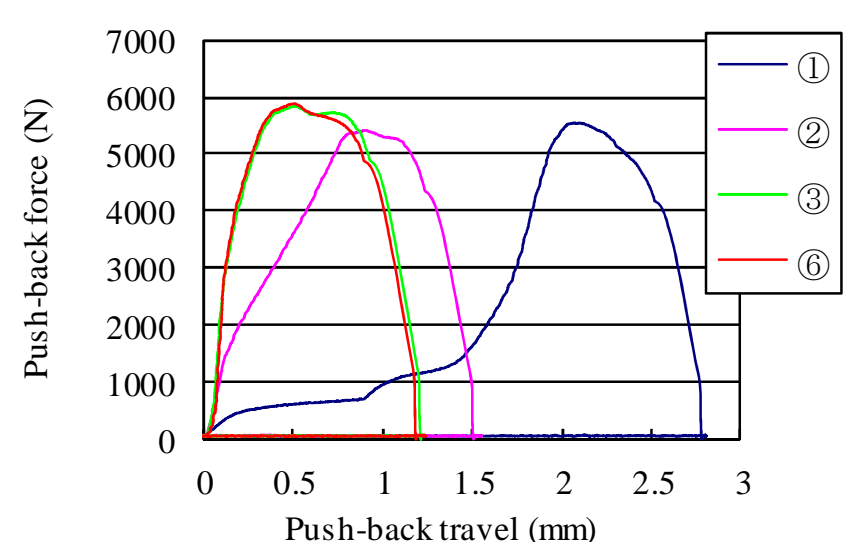

Fig.8 Shearing diagrams at 2nd stage

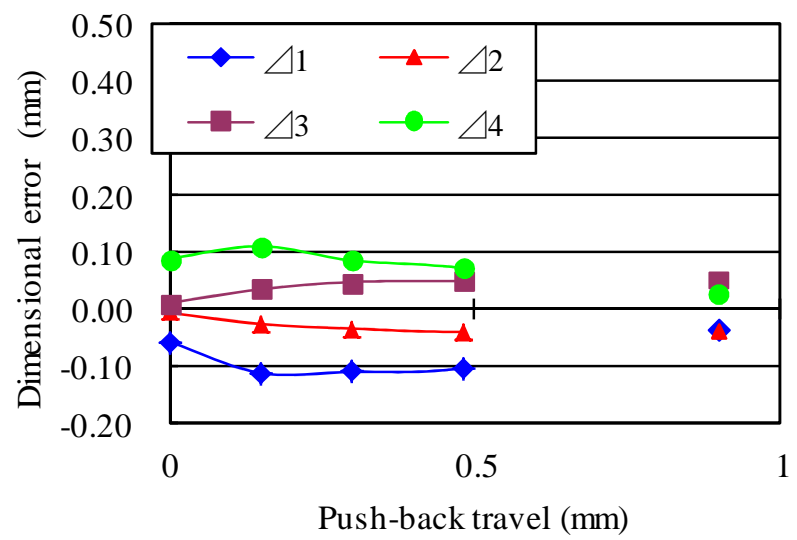

Fig.10 Variation of dimensional error for specimen (6)

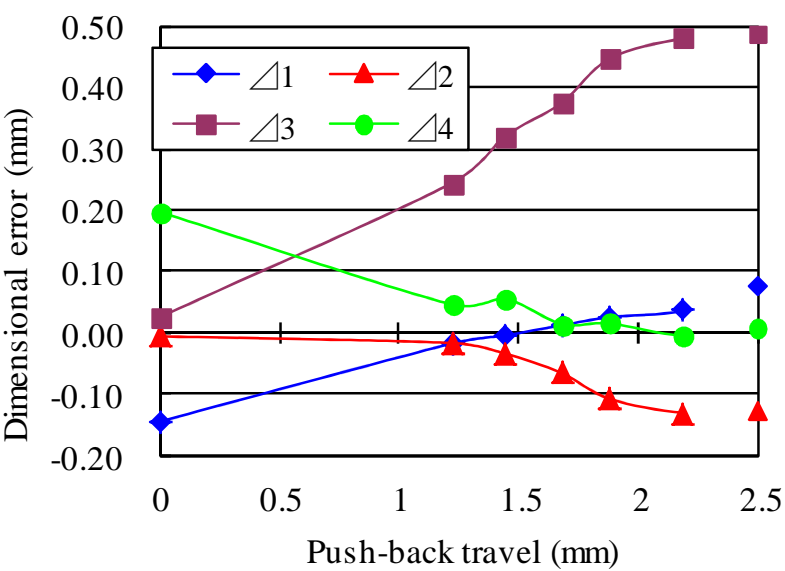

Fig.9 Variation of dimensional error for specimen(1)

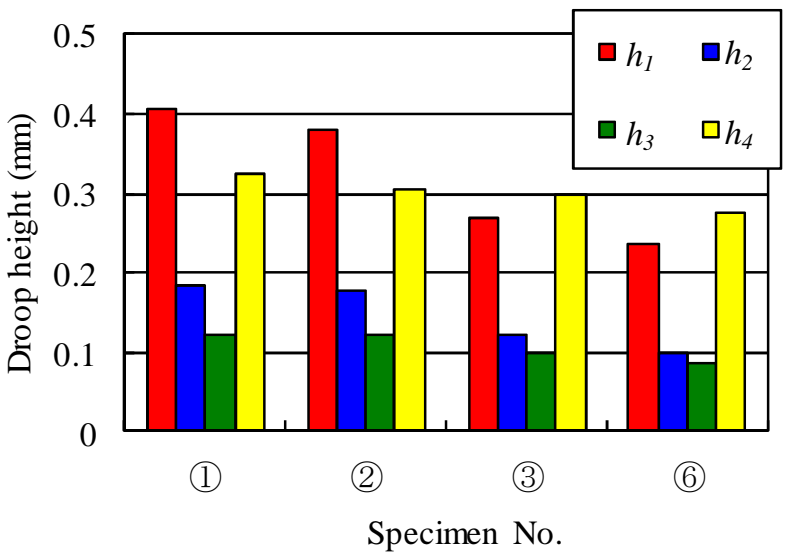

Fig.11 Comparison of droop height at 2nd stage

(4) 試験片(6)と試験片(3)を比較すると, 試験片(6)の方が製品，かすともに寸法誤差が小さくなり，板押さえ力の 大きさが誤差に影響することがわかる.

これらのことから，板押さえは $\Delta 1 ， \Delta 3$ に，逆押さえは $\Delta 2, \Delta 4$ に影響することがわかる．こうした寸法誤差 は，第 1 工程及び第 2 工程における材料変形に起因するはずである. そこで，各工程における寸法変化を調べる こととした.

\section{$4 \cdot 2$ 第 1 工程, 及び第 2 工程で生じる材料変形}

最終製品に至る過程を考えると次の誤差が考えられる. まず，第 1 工程終了後に試験片を金型から外すのでこ の際に寸法誤差を生じる，ついで第 2 工程で試験片全体が変形する.ささら製品，か寸が分離する際にも若干の 誤差を生じると考えられる. 以降，この順に考察を進める。

図 7 に第 1 工程後の試験片の寸法誤差を示す. 同図より, 全ての試験片の $\Delta 1, \Delta 4$ の誤差がきわめて大きいこ とがわかる. これは第 1 工程において生じたダイス面, パンチ面上の材料流動に起因する弾性回復と考えられる (9). この誤差は避けられないが，拘束を強固にすることで低減できる. 図 8 に第 2 工程の押し戻し線図を示す. 同図より，試験片(1)は立ち上がりがゆるやかで，押し戻し量 $1.5 \mathrm{~mm}$ 付近から慣用せん断に近づくのに比べ, 試験 片(3)，61立ち上がりが急峻であり慣用せん断の線図に類似していることがわかる．さらに，試験片(3), 試験片 (6)第 2 工程で早期に分離が完了寸るが，試験片(1)は分離に相当量の工程が必要となる.

そこで試験片(1)と試験片(6)に注目し，試験片(1)の押し戻しに伴う寸法変化を調べた. 図 9 より， $\Delta 1, \Delta 3$ は寸 法が大きくなり， $\Delta 2, \Delta 4$ は小さくなることがわかる. 特に $\Delta 3$ の変化が大きい. これは第 1 工程で生じた試験 片か寸部の跳ね上がりや, わん曲が第 2 工程で平坦化されるためである. すなわち, 製品の上側が広がるため $\Delta 1$, $\Delta 3$ が大きくなる．また製品の下側が半径方向内向きに縮むため $\Delta 2, \Delta 4$ が小さくなると考えられる．押し戻し 


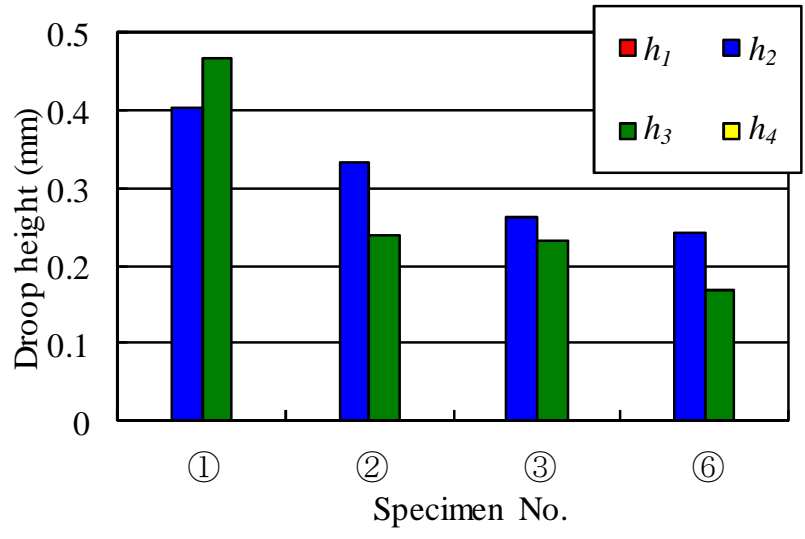

Fig.12 Comparison of droop height at 1st stage

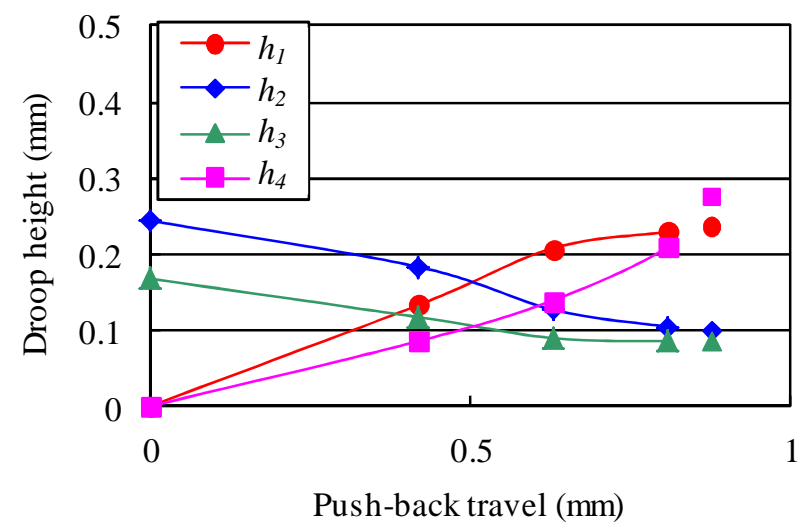

Fig.14 Variation of droop height for specimen(6)

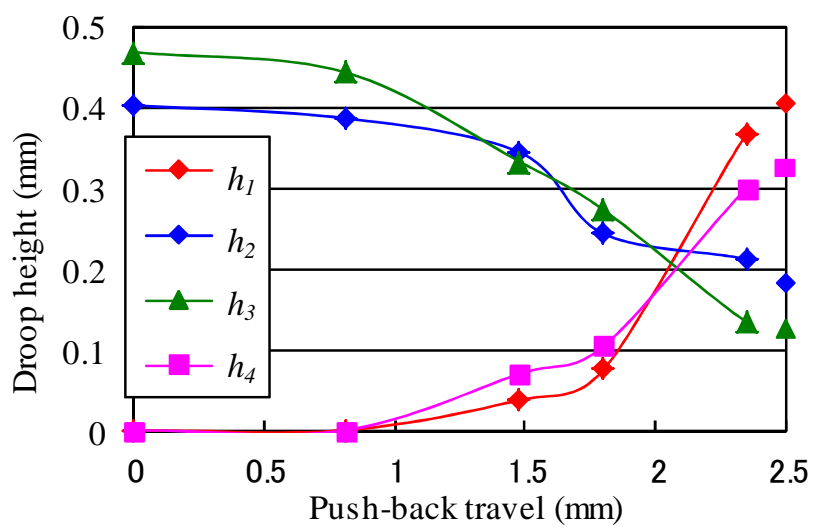

Fig.13 Variation of droop height for specimen(1)

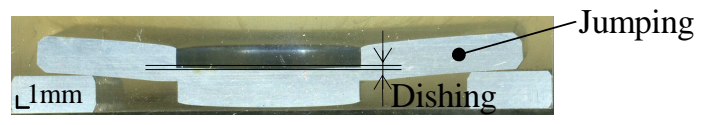

(a) Specimen (1)

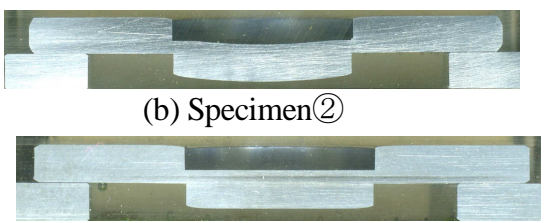

(c) Specimen(3)

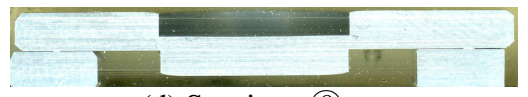

(d) Specimen (6)

Fig.15 Cross sectional view of half-blanked specimens at 1 st stage

量 $0 \sim 1.5 \mathrm{~mm}$ 付近までは，跳ね上がり部の曲げ変形やわん曲の平坦化等の余剩変形が進行し， $1.5 \mathrm{~mm}$ 付近からせ 几断的変形（仮想せん断）が始まる．以上の理由で各部の寸法誤差が生じるのである.

これに対し，第 1 工程後寸法誤差が比較的小さく，か寸部の跳㱛上がりやわん曲の少ない試験片(6)の場合を図 10 に示寸. 同図より押し戻しに伴う寸法変化がかなり小さいことがわかる. これは曲げ変形やわん曲の平坦化な ど初期に生じやすい余剩変形が少なく，速やかに仮想せん断が行われるためと考えられる．結果として全体の寸 法変化が小さく，良好な結果となっている.

さらに製品，かすが分離する際にも誤差が生じるはずであるが, 図 9, 図 10 から見るとさほど大きくない.こ れは今回用いた試験片が軟質であったためと考えられる.

\section{$4 \cdot 3$ だれ高さ}

だれ高さに関する総合的な結果を図 11 に示す.だれ $h_{2}$ と $h_{3}$ は第 1 工程でできただれが第 2 工程後減少したも のである. $h_{1}$ と $h_{4}$ は当初角部であった箇所が第 2 工程後だれとして形成されたものである. 全ての場合について 材料拘束が強いほどだれが低減する結果となっている. しかし，だれの形成過程が部位により異なるので，さら なる検討を試みた。

第 1 工程後のだれを図 12 に示す. $h_{2}, h_{3}$ のだれは板押さえ力が強固で逆押さえを用いた試験片(6)のだれが小さ くなっている. 板押さえ力を強固にした場合, 概してだれが小さくなる現象はすでに精密打抜きの研究(10) におい て報告されているとおりである. 寸なわち強固な板押さえによって板面に圧縮力が働き，材料が流動しにくくな ったためと考えられる. 試験片(1)と試験片(2)～(6)を比較すると， $h_{2}, h_{3}$ の大きさが反転している. これは板押さ えと逆押さえによって材料が拘束され，か寸部の跳㸚上がりが抑制され，材料が流動しにくくなったと考えられ る.

これらの試験片について第 2 工程における変化を以下に述べる. 試験片(1)の押し戻しに伴うだれ高さを図 13 


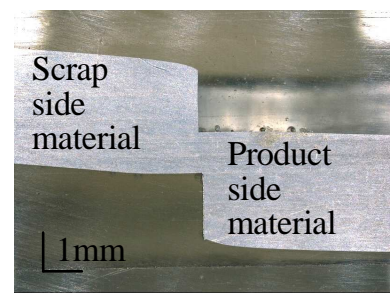

(a) As half-blanked

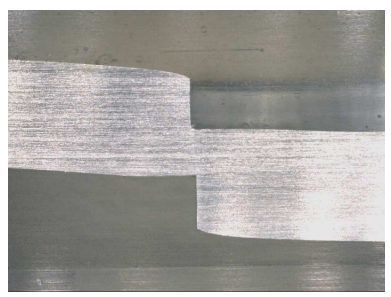

(b) Push-back travel $40 \%$

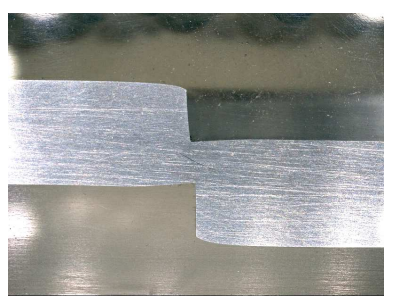

(c) Push-back travel $80 \%$

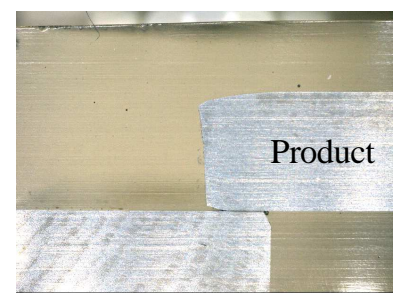

(d) Product

Fig.16 Material deformation of half-blanked specimen(1) at 2nd stage

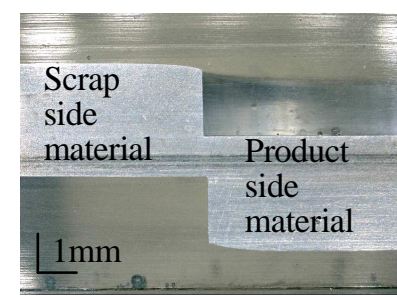

(a) As half-blanked

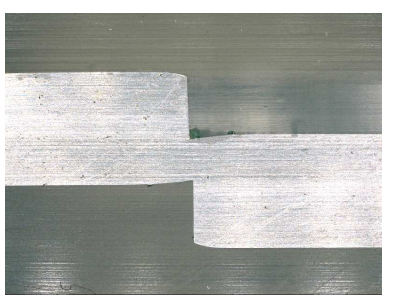

(b) Push-back travel 40\%

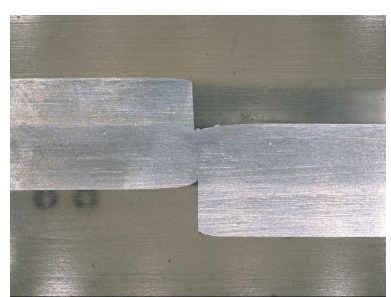

(c) Push-back travel $80 \%$

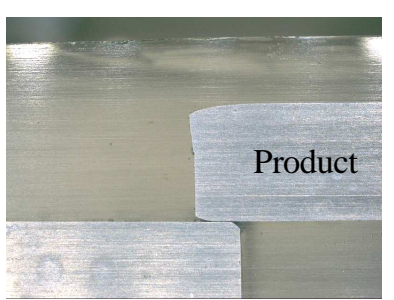

(d) Product

Fig.17 Material deformation of half-blanked specimen(3) at 2nd stage

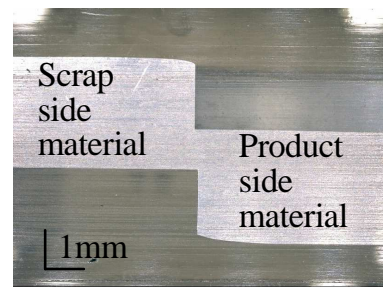

(a) As half-blanked

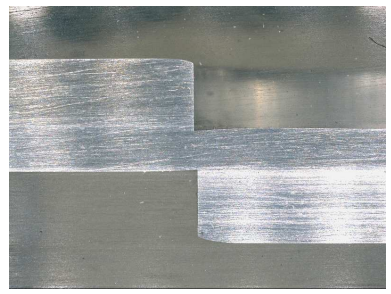

(b) Push-back travel $40 \%$

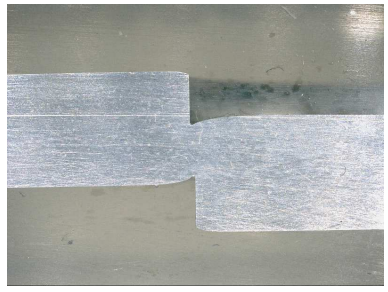

(c) Push-back travel $80 \%$

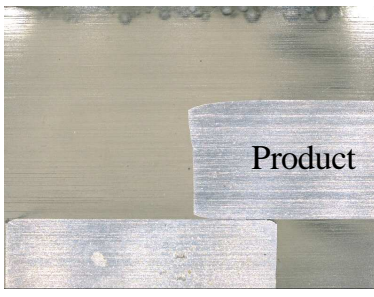

(d) Product

Fig.18 Material deformation of half-blanked specimen(6) at 2nd stage

に，試験片(6)の押し戻しに伴うだれ高さを図 14 に示寸. 図 13 より， $h_{2}, h_{3}$ は押し戻しに伴い減少し， $h_{1}, h_{4}$ は 押し戻しに伴い生成・増加している. 新たに生成されるだれ $h_{1}, h_{4}$ は第 2 工程の仮想せん断によるものである. 上述のように第 1 工程における拘束が厳しい試験片ほど，理想的な仮想せん断が行われるが，試験片(1)では図 13 のようにだれの推移が緩慢に，しかも大きな值にまで増大寸るのに比べ, 試験片(6)では図 14 のように推移は急峻 で変化量自体が小さくなっている，いずれもか寸部の跳ね上がりやわん曲等を矯正する余剩変形の有無に起因し ている.

\section{$4 \cdot 4$ 第 1 工程後の試験片の押し戻し時の変形観察}

上記の観察は第 1 工程後の製品の形状が第 2 工程に大きく影響することを述べた. そこで，第 1 工程後の製品 全体およびクリアランス近傍材料の観察を行い，これまでの説明の傍証とする.

図 15 に第 1 工程後の試験片の断面図を示寸．同図(a)より，か寸部の跳㸚上がりと製品のわん曲が見られる. 同図(b)は板押さえを用いているため, 跳ね上がりが少ないが, 製品のわん曲が見られる. 同図(c) は逆押さえを 用いているので，製品のわん曲が少ない．同図(d)は板押さえ力が強固なため，跳㸚上がりが見られず，製品のわ ん曲もほとんどない．4・2，4・3で述べたように第 1 工程後の試験片形状が寸法精度，だれに影響している.

試験片(1)を押し戻した断面図を図 16 に, 試験片(3)を押し戻した断面図を図 17 に, 試験片(6)を押し戻した断面 図を図 18 に示寸．図 16 より，押し戻しに伴いか寸の跳䄈上がりが外側に広がり，か寸部の曲げ変形が生じ，製 品のわん曲が平坦化されている. この余剩変形によって， $\Delta 1, \Delta 3$ が増加し， $\Delta 2, \Delta 4$ は減少するため寸法誤差 が生じる. 曲げ変形が進行した後, せん断的変形が行われ, 分離が完了寸る. 図 17 も傾向は同じであるが, か寸 の曲げ変形, 製品のわん曲等の余剩変形が少ない. それに比べ図 18 は変形初期から食い込み（せん断的変形）が 始まり, 余剩変形が少なく, 第 1 工程の残留板厚を押し戻すと分離が行われ, 理想的な仮想せん断が行われてい る. 

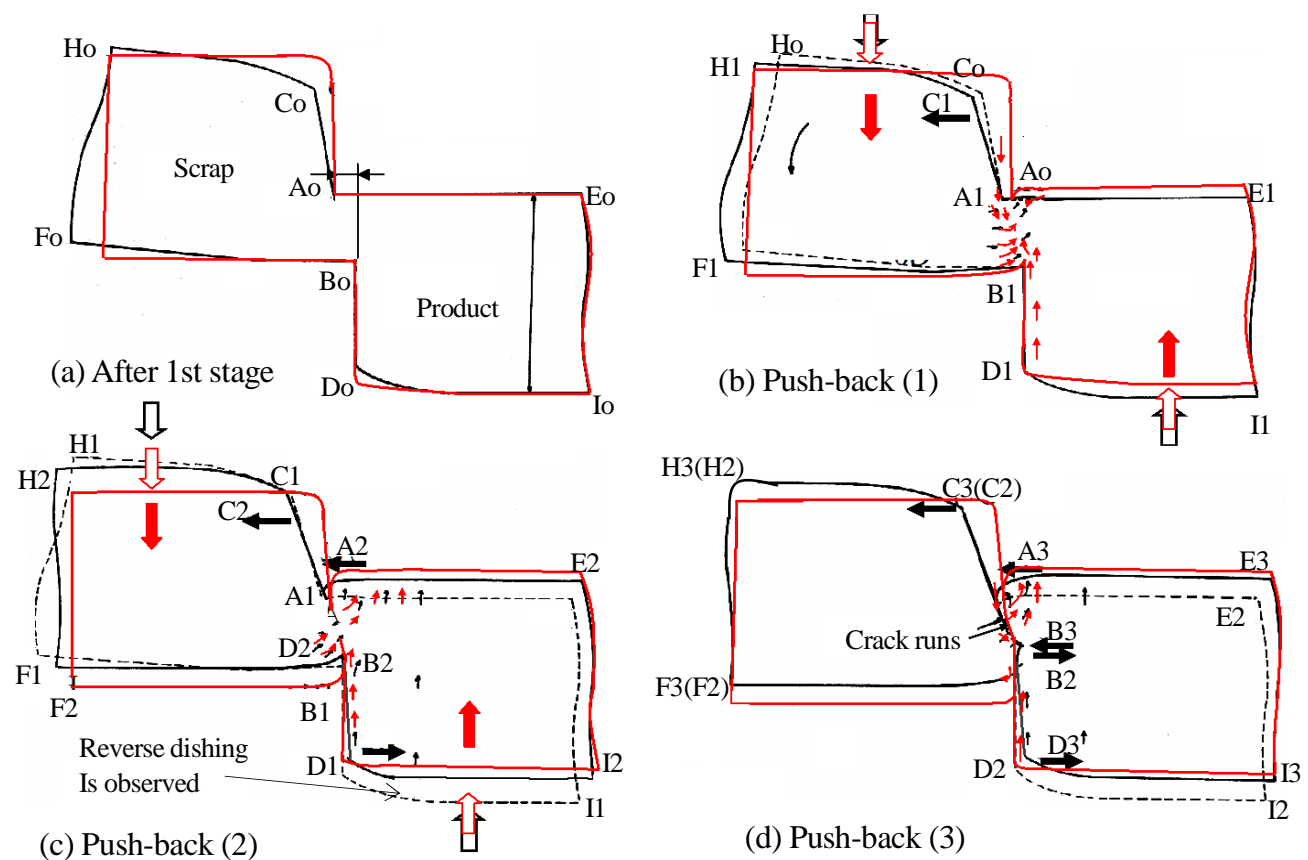

(d) Push-back (3)

Fig.19 Schematic illustration showing material deformation of half-blanked specimen at 2nd stage

製品のわん曲については以下のことがわかっている.第 1 工程完了後の半抜き製品のわん曲は図 15 に示すよう に, 試験片(1) $0.165 \mathrm{~mm}$, 試験片(2) $0.331 \mathrm{~mm}$, 試験片(3) $0.022 \mathrm{~mm}$, 試験片(6) $0.041 \mathrm{~mm}$ と逆押さえのない試験片(1),

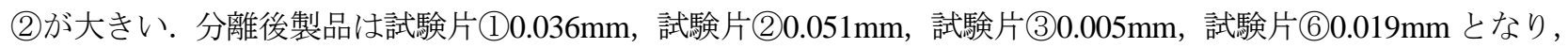
やはり，試験片(1)，(2)の值は大きいが，半抜き製品よりは減少している.これは第 2 工程の押し戻し時に平坦化 されたためと考えられる. 以上のようにわん曲に対しても逆押さえは効果があることがわかる.

\section{$4 \cdot 5$ 材料変形と寸法誤差のまとめ}

以上の実験と変形観察を元に考えた材料変形を模式的に図 19 に示寸.これは先行研究を基にしている. (11) 黒線は試験片(1), 赤線は試験片(6)模式図である. 図 19(a)は第 1 工程後の試験片形状である. 試験片(1)はか寸 側材料に跳ね上がりがあるため, AoCo の傾斜が生じている.さらに製品にわん曲が生じている，試験片6はそ れらが少ない. 図 19(b)は(a)の押し戻し過程である. 試験片(1)は押し戻しの際，か寸側が下に押し下げられ，製品 側の A1B1 で圧縮力が働き圧縮される。このことにより, AoCo が A1C1 に変化するとともに, C1 が外側に広が っていくために $\triangle 3$ が増加する. 試験片(6はすくぐせん断に入るため, 余剩変形が少ない. 図 19(c)は(b)をさらに 押し戻した状態である. 試験片(1) $\mathrm{A} 1 \mathrm{C} 1$ と B1D1 の残留板厚への食い込み，か寸側材料の寸法増加により，製 品の下側 D 1 が内側に入り，上反りすることによって， $\Delta 2$ の減少がある. また製品の上側が外側に広がるため $\Delta$ 1 が増加, か寸の下側 $\Delta 4$ が曲げ変形のよって内側に縮むため $\Delta 4$ が減少する. 試験片(6)変化が小さく, 理想的 なせん断が良好に行われている. 図 19(d)で A3 付近からのき裂により分離する.

以上, 誤差 $\Delta 1, \Delta 3$ は寸法増加, $\Delta 2, \Delta 4$ は寸法減少と考えられる. 第 1 工程の試験片が良好だとこれらの変 化が小さい. これは仮想せん断が行われ，材料変形が理想に近づくからである. 以上の考察はすでに述べた誤差 に関する実験結果を概ね説明できるものである.

\section{5. 結 言}

$3 \mathrm{~mm}$ 厚アルミニウム軟質材を用いた直径 $15 \mathrm{~mm}$ の打抜きにおけるかえりなしせん断製品の寸法精度, だれ高さ について，材料拘束の影響を実験的に検討し，以下の結論を得た。

1. 第 1 工程における寸法誤差 : 第 1 工程での寸法誤差は試験片を金型から外した際の弾性回復等による, か寸 部の跳ね上がりや製品のわん曲によって寸法誤差が大きく発生する. 板押さえを用いると，か寸の跳ね上が りは若干抑えられ，逆押さえによって製品のわん曲が抑えられる．降伏応力付近の強固な板押さえと逆押さ 
えを用いることにより, 弾性回復の影響をなくし，跳ね上がり，わん曲を防ぐことができ，第 1 工程での寸 法誤差を小さくできる.

2. 第 2 工程における寸法誤差 : 第 1 工程での試験片に跳ね上がりやわん曲があると, 第 2 工程で余剩変形が生 じ，余剰変形（か寸部の曲げ変形，わん曲の平坦化）によって，寸法誤差が大きく発生する．試験片に跳ね 上がりやわん曲がない理想的な試験片を押し戻すと, 理想的な仮想せん断が行われ, 第 2 工程の寸法変化が 小さくなる. 結果として寸法誤差が小さくなる. 本研究の場合, 材料拘束の最も強い場合は最も弱い場合に 比較し，製品パンチ側，製品ダイス側の寸法誤差はそれぞれ， $0.048 \mathrm{~mm} ， 0.102 \mathrm{~mm}$ 小さくなった.

3. 第 1 工程におけるだれ高さ : 板押さえにより材料の板面に圧縮力が働き, パンチが降下寸る際クリアランス 部に材料が流動しにくくなり，第 1 工程でできるかす側のだれ高さは小さくなる. 板押さえを強固にすると さらに圧縮力が大きくなり，さらにだれ高さが小さくなる．また逆押さえを用いることで材料を下から圧縮 力により，同様に製品側のだれ高さも小さくなる.

4. 第 2 工程におけるだれ高さ : 第 1 工程で形成されただれは, 半抜き試験片形状によらず，第 2 工程で減少す る.これは押し戻しの際，だれ部が平板によって加圧されるためであり，第 1 工程が理想的な試験片のだれ は小さい. 第 2 工程で形成されるだれは試験片形状が理想的な場合小さくなる. これは，第 2 工程で理想的 な仮想せん断が行われるためである. 本研究の場合，材料拘束の最も強い場合は最も弱い場合に比較し，製 品の第 1 工程側だれ，第 2 工程側だれはそれぞれ $0.168 \mathrm{~mm} ， 0.684 \mathrm{~mm}$ 小さくなった.

これらのことより，第 1 工程でできる試験片が理想的であれば第 2 工程での変形が理想的に行われ，寸法精度 向上，だれ低減が行えることがわかった．結果として第 1 工程の試験片を理想形状に近づける必要があり，その ためには，第 1 工程で強力な板押さえと逆押さえを用いることが効果的である.

\section{謝 辞}

本研究の一部は, 日本学術振興会科学研究費補助金（基盤研究（C), 課題番号 22560121）の支援によること を記し，謝意を表す。

\section{文献}

(1) 前田禎三, “上下抜加工法”, 機械の研究, Vol.10,No.1 (1958), pp.140-144.

(2) 牧野育雄, “かえりなしせん断法”, プレス技術, Vol.13, No.5(1975), pp.93-98.

(3) Liebing, H., "Counter-Blanking -A Shearing Process for Producing Blanking without Any Burr-", Proceedings of the 18th International Machine Tool Design and Research conference, (1975), pp.369-375.

(4) 青木勇, 前田禎三, “かえりなしせん断の加工機構に関する実験的検討”, 塑性と加工, Vol.32, No.364(1991), pp.621-626.

(5) 青木勇, 堀口孝司, 初元璋, “かえりなしせん断機構に関する実験的検討 第 2 報（加工機構と打抜き製品に及 ぼす加工条件の影響)”, 塑性と加工, Vol.35, No.399(1994), pp.361-366.

（6）青木勇，高橋俊典，“かえりなしせん断加工特性に及ぼすさん幅の影響”，塑性と加工，Vol.39, No.445(1998), pp.131-136.

(7) 広田健治, 近藤一義, “かえりなしせん断法 (平押し法) における負クリアランス条件拡張の影響”, 塑性と加 工, Vol.40, No.456(1999), pp.361-366.

(8) Sutasn, T., 神雅彦, 村川正夫, “2 工程上下抜き法における加工条件と打抜き品形状との関係の解明（かえり無 し打抜き加工に関する研究 第 1 報)”，塑性と加工，Vol.43, No.494(2002), pp.209-213.

（9）笹田昌弘, 佐藤不思議, 青木勇, “世ん断加工における被加工材料の変形に関する研究（クリアランス及び被加 工材料直径の影響)”, 日本機械学会論文集 C 編, Vol.78, No.795(2012), pp.3768-3775.

（10）中川威雄, 鈴木清, 木下素男, “精密打抜き製品に及ぼす製品輪郭形状の影響”, 塑性と加工, Vol.12, No.129(1971), pp.742-751.

(11) Maeda, T., Aoki, I., "The Development of Burr-Free Blanking: Roll Blanking", Journal of the Faculty of Engineering, The University of Tokyo, Vol.35,No.4(1980), pp.753-767. 